\title{
DESAIN DIALOG MAHASISWA MENGGUNAKAN POSITIVE REINFORCEMENT DAN FACEBOOK
}

\author{
Habibi \\ Universitas Wiraraja \\ habibi.bk13@Gmail.com
}

\begin{abstract}
ABSTRAK
Dialog antar mahasiswa dan dosen dalam perkuliahan dapat meningkatkan kemampuan berkomunikasi, menganalisis dan juga memperluas materi perkuliahan agar menjadi lebih kontekstual. Studi pendahuluan di Prodi Pendidikan IPA Universitas Wiraraja menunjukkan bahwa dialog mahasiswa di dalam perkuliahan masih minim. Perkembangan teknologi informasi seperti facebook yang sangat digemari mahasiswa sebenarnya sangat potensial digunakan untuk mengembangkan dialog pendukung perkuliahan. Penelitian ini bertujuan untuk mengembangkan dialog mahasiswa menggunakan positive reinforcement dan facebook. Tujuan spesifik pada tahapan ini adalah (1) mendeskripsikan permasalahan yang dihadapi mehasiswa untuk dapat terlibat aktif dalam dialog, dan (2) mendesain suatu aktivitas dialog mahasiswa berdasarkan solusi atas permasalahan yang mereka hadapi tersebut. Metode penelitian yang digunakan adalah deskriptif kualitatif. Teknik pengumpulan data dengan menggunakan penyebaran angket, wawancara dan observasi. Istrumen yang digunakan adalah angket, pedoman wawancara dan lembar observasi. Teknik analisis yang digunakan adalah analisis interaktif yang diadobsi dari Miles dan Huberman (1992). Hasil analisis memberi temuan bahwa permasalahan dialog mahasiswa meliputi (1) kurang percaya diri, (2) pujian bersifat nonspesifik dan (3) keterbatasan waktu. Berdasarkan pokok-pokok permasalahan tersebut dialog mahasiswa didesain dengan menggunakan teknik (1) penilaian keaktifan, (2) pujian spesifik dan (3) grup diskusi di facebook.
\end{abstract}

Kata Kunci: dialog mahasiswa, analisis interaktif, facebook

\section{PENDAHULUAN}

Pembelajaran terjadi secara maksimal melalui proses yang aktif. Secara sederhana para ahli pendidikan konstruktivistik (Moreno, 2010) menjelaskan bahwa belajar merupakan proses konstruksi pengetahuan atau keterampilan tertentu yang diperoleh seseorang melalui interaksi dengan individu lain atau lingkungan di sekitarnya (pengalaman).

Keaktifan peserta didik tidak hanya berupa dalam aktivitas yang membutuhkan gerak dan keterampilan motorik (hands on activity) tetapi juga berupa aktivitas yang membuat mereka dapat menggunakan pikirannya (minds on activity) seperti memahami, menganalisis dan mengkomunikasikan informasiinformasi terkait materi yang dipelajari. Proses belajar dapat juga kita lihat sebagai proses interaksi sosial yang unsur utamanya adalah komunikasi. Vygotsky melalui teori mediasi kognitif (Habibi, 2012) menekankan betapa pentingnya interaksi sosial dalam proses pembelajaran. Dalam proses mediasi tersebut pengajar mengarahkan para peserta didik untuk meningkatkan kemampuan kognitifnya melalui komunikasi atau dialog.

Pentingnya komunikasi atau dialog dalam proses pembelajaran telah disadari dan diimplementasikan oleh para pengajar sejak zaman klasik. Sejarah pengajaran klasik Yunani menceritakan bahwa para filsuf ternama seperti Socrates, Plato dan Aristoteles menggunakan dialog (dialektika) sebagai sarana untuk mengajar (Kattsoft, 2008). Proses pengajaran yang dilakukan saat ini, berdasarkan penelitian, juga tetap menunjukkan tentang pentingnya dialog atau komunikasi dalam pembelajaran. 
Andrews, Kalinowski \& Leonard (2011) dari Montana State University dalam penelitiannya menggunakan tiga tahapan diskusi yaitu (1) memunculkan konsepsi naif (yang masih salah) dari siswa, (2) menguji konsepsi-konsepsi nonilmiah tersebut dan (3) menguatkan kerangka konseptual melalui pengajaran. Penerapan diskusi yang mengarahkan mahasiswa untuk secara dialogis membandingkan pemahaman awal yang mereka miliki dengan mekanisme seleksi alam secara terbimbing rupanya benarbenar dapat mengatasi permasalahan miskonsepsi. Tercatat sebesar $78 \%$ mahasiswa yang mengawali diskusi dengan pemahaman yang kurang tepat tentang evolusi ternyata dapat memperperbaiki kesalahan dalam pemahaman tersebut. Selain itu juga didapatkan peningkatan hasil belajar yang signfikan dalam tema yang dipelajari.

Penelitian lain yang juga mendukung kemampuan metode diskusi untuk meningkatkan pemahaman peserta didik adalah yang dilakukan oleh
Setyowati, Subali dan Mosik (2011) dari Universitas Negeri Semarang. Dalam penelitian tersebut konflik kognitif tidak hanya dihadirkan dan diselesaikan dalam diskusi melainkan juga dibantu dengan metode demonstrasi dan eksperimen. Penyisipan metode demonstrasi dan eksperimen sesuai dengan karakter hand on - mind on dalam pembelajaran IPA. Hasilnya terjadinya penurunan miskonsepsi dari $45,08 \%$ menjadi $27,83 \%$.

Berdasarkan observasi prapenelitian, kondisi mahasiswa Prodi Pendidikan IPA Universitas Wiraraja yang menjadi fokus penelitian ini masih kurang aktif dalam dialog perkuliahan yang diadakan oleh dosen (Tabel 1). Selain itu kualitas dialog yang terjadi belum menunjukkan adanya suatu interaksi untuk melakukan pencarian kebenaran pada level berpikir tingkat tinggi. Pertanyaan ataupun pendapat mahasiswa berdasarkan observasi peneliti masih didominasi level pengetahuan faktual ataupun pemahaman.

Tabel 1. Keaktifan Mahasiswa dalam Dialog Perkuliahan

\begin{tabular}{lccc}
\hline Nama Mata Kuliah & Mahasiswa aktif & Mahasiswa kurang aktif & Mahasiswa Pasif \\
\hline Pembelajaran IPA 1 & $28 \%$ & $27 \%$ & $45 \%$ \\
\hline Pembelajaran IPA 3 & $17 \%$ & $51 \%$ & $32 \%$ \\
\hline
\end{tabular}

Sumber : Tabulasi keaktifan mahasiswa di Prodi Pendidikan IPA UNIJA Semester Ganjil 2013/2014

Partisipasi dalam dialog ilimiah yang dilakukan oleh mahasiswa dalam perkuliahan dipengaruhi oleh faktor internal (yaitu kemauan mahasiswa) dan faktor eksternal seperti keterbatasan waktu bertanya atau berpendapat dalam perkuliahan. Untuk itu, pengembangan perkuliahan yang dapat meningkatkan kuantitas dan kualitas dialog ilmiah mahasiswa harus meliputi kedua faktor tersebut. Berdasarkan kedua faktor tersebut penelitian ini dilakukan. Prinsip positive reinforcement diharapkan dapat mengatasi permasalahan internal mahasiswa (kemauan), sedangkan penggunaan facebook diharapkan dapat mengatasi permalahan eksternal (keterbatasan waktu).

Uji coba penggunaan facebook untuk mendukung interaksi perkuliahan dilaporkan oleh Ventura dan Quero (2013) dari Universitas Malaga, Spanyol. Dalam artikel tersebut dijelaskan bahwa uji coba penggunakan facebook untuk mendukung perkuliahan (terutama interaksi di antara mahasiswa ataupun dengan dosen) dilakukan pada mata kuliah Business Economics II. Dibuat grup dalam facebook khusus untuk mata kuliah tersebut (jumlah anggota terakhir adalah 166 orang). Di akhir perkuliahan dilakukan survey terhadap mahasiswa mengenai opini mereka terhadap inisiatif 
penggunaan facebook untuk mendukung perkuliahan. Hasil dari survey menunjukkan bahwa rata-rata (dengan nilai 4,1 dari skala maksimal 5) menyetujui penggunaan facebook untuk mendukung perkuliahan. Mereka juga mendukung pendapat bahwa facebook memberikan dampak positif terutama untuk memotivasi mereka memahami materi kuliah (Gambar 1).

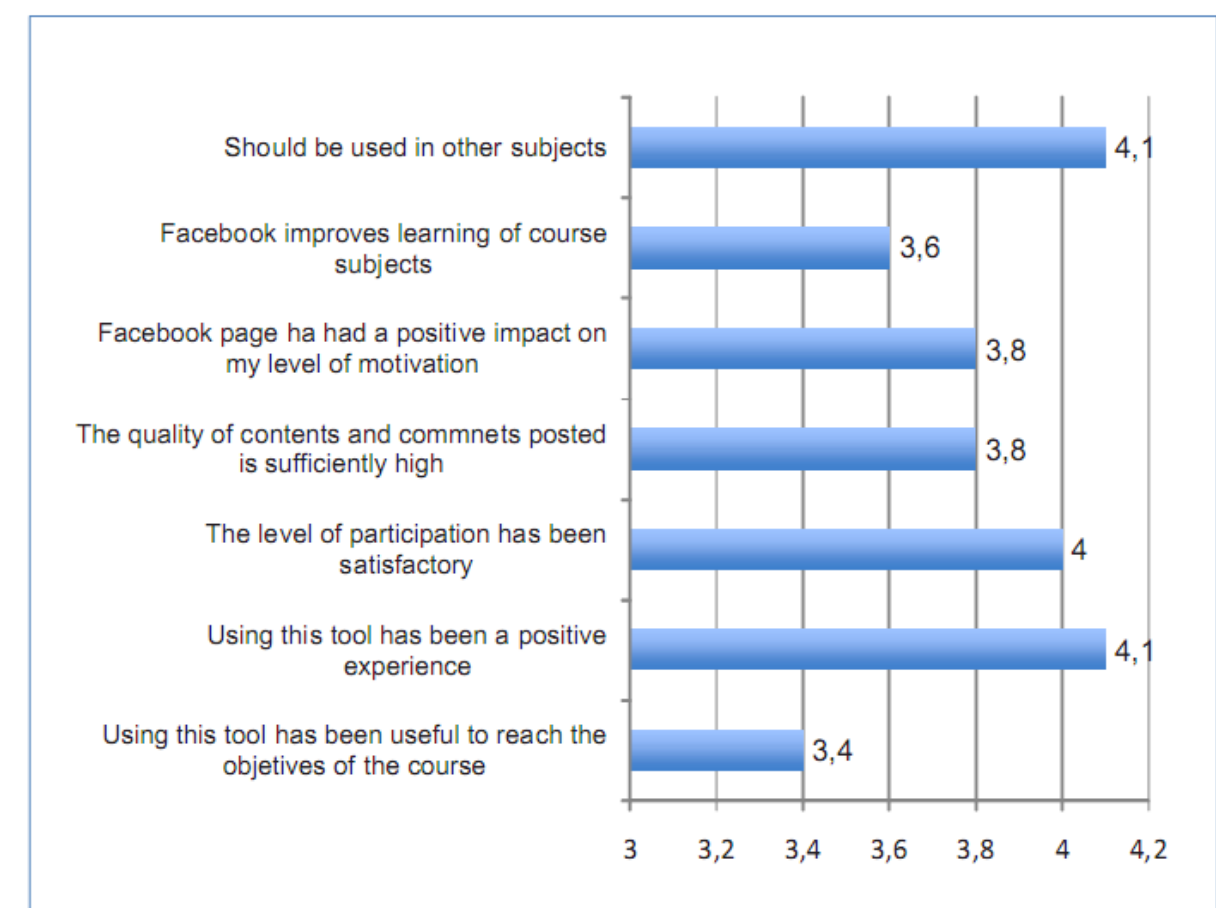

\section{Gambar 1. Hasil Survey terhadap Mahasiswa Mengenai Penerapan Facebook (Sumber : Ventura \& Quero, 2013)}

Berdasarkan latar belakang di atas penelitian ini memiliki dua tujuan utama yaitu : (1) Mengeksplorasi kendala yang dihadapi mahasiswa Prodi Pendidikan IPA Univeritas Wiraraja Sumenep untuk berpartisipasi dalam dialog ilmiah dan (2) Membuat desain perkuliahan menggunakan positif reinforcement dan facebook yang dapat meningkatkan kualitas dialog mahasiswa Prodi Pendidikan IPA Universitas Wiraraja Sumenep.

\section{METODE}

Penelitian ini termasuk ke dalam jenis penelitian pengembangan ( $R$ and $D)$. Jenis penelitian ini dipilih berdasarkan tujuan penelitian untuk mengembangkan suatu perkuliahan yang dapat meningkatkan kualitas dialog mahasiswa dengan menggunakan prinsip penguatan positif (positive reinforcement) dan media jejaring sosial (social network). Model pengembangan yang digunakan adalah Model ADDIE yang diadobsi dari Branch (2009). Tahapan pengembangan pada model ADDIE adalah lima tahapan yang terdiri dari Analysis, Design. Develop, Implement dan Evaluate. Lebih jelasnya kelima tahapan tersebut adalah sebagai berikut:

1. Analisis (Analyze)

Pada tahapan analisis dilakukan eksplorasi mengenai kesenjangan antara tujuan dengan realitas yang terjadi dalam perkuliahan, Penentuan tujuan pengembangan, mengonfirmasi kondisi mahasiswa dan membuat perencanaan anggaran.

2. Desain (Design)

Pada tahapan desain dilakukan inventarisasi aktivitas-aktivitas yang harus dilakukan oleh mahasiswa berdasarkan kesenjangan yang 
teridentifikasi pada tahap analisis, menetapkan tujuan-tujuan pembelajaran, strategi atau metode dan teknik penilaiannya.

3. Mengembangankan (Develop) Pada tahapan pengembangan dilakukan penyusunan perangkatperangkat perkuliahan berdasarkan rancangan pada tahap desain. Selain itu juga dilakukan validasi perangkat dengan mengadakan pilot test.

4. Implementasi (Implement)

Pada tahapan implementasi dilakukan penerapan perangkat perkuliahan pada proses perkuliahan yang sebenarnya. Berbagai persiapan yang harus dikuasai oleh guru harus dimatangkan sebelum penerapan berlangsung. Demikian pula dengan berbagai aktivitas mahasiswa yang diharapkan.

5. Evaluasi (Evaluate)

Pada tahapan evaluasi dilakukan penilaian menyeluruh mengenai kualitas desain perkuliahan mulai dari sebelum implementasi hingga setelah implementasi. Kriteria penilaian ditentukan secara seksama terutama berdasarkan indikatorindikator yang disusun pada tahapan desain.

Artikel ini hanya meliputi tahap 1 (analisis) dan 2 (desain). Pada tahap analisis dieksplorasi dasar permasalahan kualitas dialog mahasiswa dalam perkuliahan di Prodi Pendidikan IPA FKIP Universitas Wiraraja Sumenep. Berdasarkan permasalahan tersebut lalu dilakukan proses desain. Pengumpulan data menggunakan teknik observasi dan wawancara mendalam. Adapun teknik analisis data yang digunakan pada tahapan analisis adalah analisis model interaktif yang diadobsi dari Miles dan Huberman (1992). Analisis model interaktif terdiri atas empat subanalisis yaitu pengumpulan data, reduksi, penyajian data dan kesimpulan (Lihat Gambar 2). Keempat subanalisis tersebut dilakukan berulang-ulang hingga mendapatkan data yang jenuh, sesuai dengan fokus penelitian.

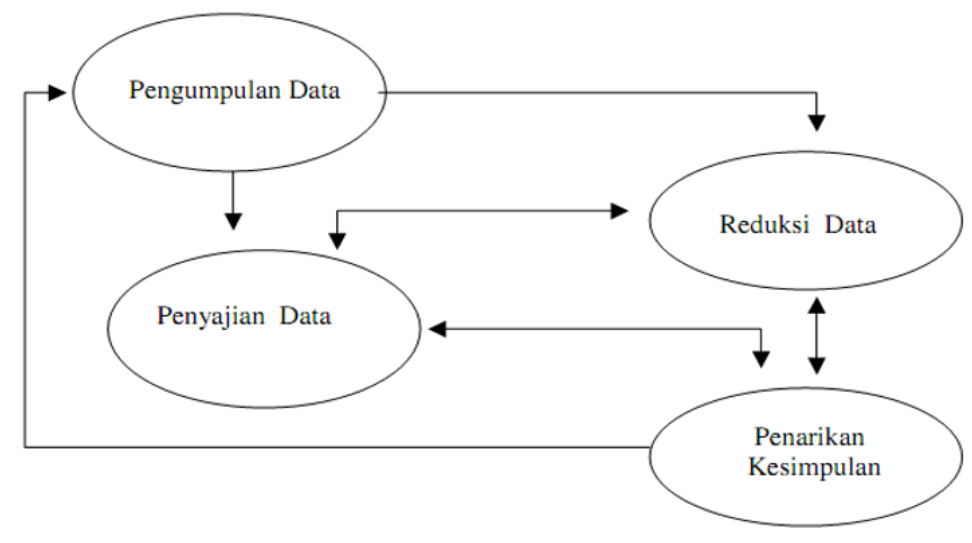

Gambar 2. Analisis Interaktif (Miles \& Huberman, 1992)

\section{HASIL DAN PEMBAHASAN \\ Tahap Analisis}

Berdasarkan temuan penelitian pada tahapan analisis terdapat tiga katagori permasalahan dasar yang membuat mahasiswa banyak yang tidak dapat berpartisipasi secara aktif dalam dialog perkuliahan. Ketiga katagori permasalahan tersebut adalah; (1) kurang percaya diri akan kemampuan menyusun kalimat, (2) pujian tidak spesifik dan (3) waktu yang terbatas untuk mengakomodasi seluruh mahasiswa. Berikut deskripsi dari ketiga permasalahanyang ditemukan.

1. Kurang Percaya Diri akan Kemampuan Menyusun Kalimat Penyebab utama kesulitan mahasiswa untuk berpartisipasi dalam dialog adalah kurang percaya diri untuk 
menyusun dan menyampaikan kalimat-kalimat secara lisan. Berdasarkan latar belakang sekolah yang mereka jalani, para mahasiswa sebagian besar tidak dibesarkan dalam suasana kelas yang dialogis. Hal tersebut menyebabkan mereka menjadi grogi, tidak percaya diri dalam menyusun kalimat yang akan diungkapkan dan pada akhirnya menjadi pasif. Berikut ini merupakan salah satu ungkapan mahasiswa terkait dengan kurangnya rasa percaya diri sebagai penyebab pasifnya mereka dalam aktivitas dialog.

"Malu pak. Pada satu ketika dalam mata kuliah bapak saya bertanya, ternyata teman saya yang berada di dekat saya yaitu Nur Hikmah Putri Ayu juga ngomong kalau sebenarnya dia juga ingin bertanya tapi sulit. "gimana ya saya nggak bisa cara bicaranya, tidak bisa mengungkapkan pertanyaannya. Saya takut nanti malah memalukan dan tidak bisa bicara padahal sudah mengacungkan tangan." Pokoknya pesimis gitu lah pak. Saya tanya "kalau kamu terus begini terus gimana, kan gak bisa aktif padahal ada penilaian untuk keaktifan." Ya sudah lain kali saja."

\section{Pujian tidak Spesifik}

Pada beberapa mata kuliah yang diobservasi diketahui bahwa dosen telah menggunakan penguatan (reinforcement) positif berupa pujian untuk menguatkan mental mahasiswa. Bahkan untuk setiap keberanian mahasiswa berpendapat pujian diberikan. Harapannya semakin banyak mahasiswa yang terdorong untuk ikut berpartisipasi, mengalahkan rasa kurang percaya diri mereka. Pujian yang diberikan dalam perkuliahan yang diobservasi merupakan pujian umum seperti perkataan "bagus" atau "pertanyaan yang baik." Pujian seperti ini tidak disertai dengan penjelasan mengenai apa yang menjadikan pertanyaan atau pendapat mahasiswa disebut bagus atau baik. Kemungkinan besar tidak efektifnya pujian yang tidak spesifik adalah anggapan mahasiswa (yang sudah memiliki kemampuan memahami pola-pola perilaku sosial dengan baik) bahwa pujian tersebut hanya merupakan tatakrama (dalam bahasa sehari-hari sering disebut dengan basa-basi). Berikut ini hasil observasi peneliti (observasi berperan serta) yang menunjukkan kondisi pujian tidak spesifik.

"Setiap kali mahasiswa mengutarakan pertanyaan atau pendapatnya sebisa mungkin jika ingat, saya memberikan penghargaan seperti "pertanyaan yang bagus." Harapan saya agar mereka lebih bersemangat untuk aktif serta menghilangkan ketakutan atau rasa tidak percaya diri bagi mereka yang masih belum aktif."

3. Waktu yang Terbatas untuk Mengakomodasi Seluruh Mahasiswa Temuan ketiga dalam penelitian ini yang menunjukkan permasalahan kualitas dialog dalam perkuliahan adalah mengenai waktu. Setiap partisipasi mahasiswa membutuhkan waktu yang cukup banyak. Apalagi jika pendapat atau pertanyaan mereka nantinya diarahkan untuk ditanggapi oleh mahasiswa lain. Hal ini tentu saja membuat waktu yang tersedia tidak mungkin mencukupi untuk mengakomodasi seluruh mahasiswa (jumalah mahasiswa yang diamati berkiasar antara 30 hingga 40 orang). Kondisi ini membuat mahasiswa yang kurang percaya diri dan lambat dalam mengumpulkan keberaniannya akan kehilangan kesempatan untuk berpartisipasi. Berikut ini adalah salah satu hasil observasi (berperan serta) yang menunjukkan keterbatasan waktu sebagai permasalahan untuk mengakomodasi partisipasi seluruh mahasiswa dalam dialog. 
"Kondisi kelas yang penuh sesak dengan alokasi waktu dua SKS membuat saya sangat dibatasi waktu. Penjelasan konsep dan contoh-contoh kongkrit mengenai beberapa pemikiran filsuf modern seperti descartes dan Galileo yang berpengaruh terhadap perkembangan sains tidak dapat disajikan secara leluasa. Belum lagi saya harus memberikan hak mahasiswa untuk turut berpartisipasi berupa pengajuan pertanyaan ataupun pendapatpendapat pribadi. Empat pertanyaan mahasiswa saya bahas selama perkuliahan. Awalnya saya melihat beberapa mahasiswa lain juga mengangkat tangannya sebagai isyarat untuk bertanya, namun karena waktu yang sudah melewati batas akhir kuliah tampaknya beberapa di antara mereka mengurungkan niatnya."

\section{Tahap Desain}

Berdasarkan tiga permasalahan pokok dalam pelaksanaan dialog perkuliahan di atas maka peneliti menyusun suatu desain pelaksanaan dialog perkuliahan yang memungkinkan pertisipasi yang lebih baik. Dengan menggunakan teknik desain dalam model ADDIE, peneliti melakukan proses (1) penentuan rumusan tujuan, (2) penentuan materi dialog, (3) pengembangan instrument dialog dan (4) merancang metode pelaksanaan dialog. Secara ringkas desain dapat dilihat pada Tabel 2.

1. Rumusan Tujuan

Berdasarkan permasalahan atau kendala yang terjadi dalam pelaksanaan dialog yang ditemukan maka disusun rumusan tujuan dari penelitian pengembangan ini. Adapun rumusan tujuan tersebut adalah sebagai berikut:

a. Mahasiswa dapat berpartisipasi aktif dalam dialog yang berlangsung dalam perkuliahan maupun di luar perkuliahan. b. Mahasiswa dapat merasa lebih percaya diri untuk menyusun kalimat dalam dialog yang berlangsung dalam perkuliahan maupun di luar perkuliahan.

2. Materi Dialog

Materi dialog tidak ditentutkan secara khusus oleh peneliti di luar konteks perkuliahan. Materi yang digunakan dalam dialog nantinya adalah sesuai dengan silabus dan kontrak perkulaihan yangbakan menjadi kelas penerapan dari desain yang dihasilkan.

3. Instrumen Dialog

Instrumen yang dikembangkan untuk mendukung proses dialog dalam penelitian ini meliputi dua instrument yaitu lembar pencatatan keaktifan dialog mahasiswa dan group facebook yang khusus dibuat dengan mahasiswa peserta matakuliah eksperimen dialog sebagai anggotanya.

4. Metode Pelaksanaan Dialog

Metode yang digunakan untuk mendorong partisipasi mahasiswa dlam dialog adalah menggunakan prinsip positif reinforcement dengan dua bentuk. Pertama adalah pencatatan setiap mahasiswa yang berpartisipasi dalam dialog untuk nantinya akan diberikan tambahan nilai. Kedua adalah pemberian pujian spesifik, artinya pujian diberikan pada partisipasi mahasiswa tidak hanya dalam bentuk yang umum seperti "baik" atau "bagus." Secara khusus pujian meliputi aspek-aspek positif dalam pendapat datau pertanyaan mahasiswa. Selain akan menghilangkan kesan pujian sebagai "basa-basi" atau formalitas, diharapkan pujian spesifik akan dapat meningkatkan kualitas mahasiswa dalam menyusun kalimat baik secara structural maupun muatan yang terkandung dalam kalimat. Selain prinsip tersebut juga dilakukan perluasan dialog di luar perkuliahan dengan memanfaatkan teknologi informasi yaitu facebook. 
Tabel 2. Desain Dialog Menggunakan Positive Reinforcement dan Facebook

\begin{tabular}{clll}
\hline No & \multicolumn{1}{c}{ Rumusan Tujuan } & \multicolumn{1}{c}{ Metode } & \multicolumn{1}{c}{ Instrumen } \\
\hline 1 & $\begin{array}{l}\text { Mahasiswa dapat berpartisipasi aktif } \\
\text { dalam dialog yang berlangsung dalam } \\
\text { perkuliahan maupun di luar perkuliahan. }\end{array}$ & $\begin{array}{l}\text { Pemberian nilai dan } \\
\text { pujian spesifik. }\end{array}$ & $\begin{array}{l}\text { Lembar pencatatan } \\
\text { keaktifan dialog mahasiswa } \\
\text { dan group facebook }\end{array}$ \\
\hline 2 & $\begin{array}{l}\text { Mahasiswa dapat merasa lebih percaya } \\
\text { diri untuk menyusun kalimat dalam dialog } \\
\text { yang berlangsung dalam perkuliahan } \\
\text { maupun di luar perkuliahan. }\end{array}$ & $\begin{array}{l}\text { Memperluas waktu dialog } \\
\text { di luar perkuliahan. }\end{array}$ & Group facebook \\
\hline
\end{tabular}

\section{KESIMPULAN DAN SARAN}

Kesimpulan yang dihasilkan dalam penelitian ini adalah sebagai berikut:

1. Kendala dasar keaktifan mahasiswa Prodi Pendidikan IPA dalam dialog perkuliahan adalah kurang percaya diri, pujian nonspesifik dan terbatasnya waktu.

2. Desain perkuliahan untuk meningkatkan kualitas dialog mahasiswa berdasarkan ketiga kendala dasar di atas meliputi pengembangan metode dan instrumen. Metode yang dikembangkan adalah penilaian keaktifan dan pujian spesifik, sedangkan instrumen yang dikembangkan adalah Lembar Pencatatan Keaktifan Mahasiswa dan group facebook.

Berdasarkan hasil penelitian berupa desain dialog perkuliahan menggunakan prinsip positive reinforcement dan facebook diharapkan kualitas partisipasi mahasiswa dalam dialog akan meningkat. Namun sebenarnya kualitas desain ini masih dapat ditingkatkan jika saja tanggapan mahasiswa akan dialog melalui facebook telah didapatkan (setelah fase implementasi). Kualitas desain dapat ditingkatkan dengan menggunakan teknik pengelolaan laman facebook yang disesuaikan dengan karakter mahasiswa baik dari aspek isi maupun fitur facebook itu sendiri. Untuk itu disarankan dalam tahapan implementasi ke depan, feedback dari mahasiswa juga menjadi fokus penelitian terutama terkait dengan kenyamanan dan ketertarikan mareka dalam melakukan dialog.

\section{DAFTAR RUJUKAN}

Andrews, T.M. Kalinowski, S.T. \& Leonard, M.J. 2011. "Are Humans Evolving?" A Classroom Discussion to Change Student Misconceptions Regarding Natural Selection. Evo Edu Outreach. Vol. 4. Hal: 456-466

Branch, Robert M. 2009. Instructional Design: The ADDIE Approach. New York: Springer

Habibi. 2012. Pengantar Teori Belajar. Sumenep: UNIJA Press

Habibi. Anekawati, Anik \& Faizah, Lutfiana F. 2010. Permasalahan Pembelajaran IPA SMP/MTs di Kabupaten Sumenep. Sumenep: Universitas Wiraraja

Miles, M. B. \& Huberman, A.M. Analisis Data Kualitatif: Buku Sumber tentang Metode-metode Baru. Jakarta: UI Press.

Moreno, Roxana. 2010. Educational Psychology. New Mexico: John Wiley \& Sons, Inc.

Setyowati, A. Subali, B. \& Mosik. 2011. Implementasi Pendekatan Konflik Kognitif dalam Pembelajaran Fisika untuk Menumbuhkan Kemampuan Berpikir Kritis Siswa SMP Kelas VIII. Jurnal Pendidikan Fisika Indonesia. Vol 7. No. 2. Hal: 89-96

Ventura, Rafael \& Quero, M.J. 2013. Using Facebook in University Teaching: A Practical Cased Study. Procedia-Social and Behavioral Sciences. Vol. 8. Hal: 1032-1038 
Jurnal Lentera Sains (Lensa)

24 Jurnal Lensa, Volume 5 Jilid I Mei 2015 